\title{
This is What Democracy Sounds Like: Live and Mediated Soundscapes of the Wisconsin Uprising
}

\author{
MICHAEL S. O'BRIEN
}

The Wisconsin Uprising, a movement of pro-labor activism that broke out in early 2011 in response to Wisconsin Governor Scott Walker's proposed union-busting "Budget Repair Bill," was exceptional in its intensity and breadth, attracting tens of thousands of protesters to the state capitol over weeks and culminating in recall elections for nearly a dozen elected officials of both parties. The movement was also exceptional for its central and innovative uses of music and sound, in both live and in mediated forms. Over the course of six months in 2011, I witnessed dozens of cases of music making in the service of political protest, including mass song, performances by amateur and professional bands (marching, rock, pipe and drum, and many others), Broadway-inspired flash mobs, and other events. Virtual and other mediated sonic performances were just as common; protesters created homemade music videos, audio recordings and lyric sheets, all of which circulated through social media platforms and other web services. Some of these mediated presentations of live musical protest began to emerge in a complex and even symbiotic relationship with those live events themselves, reflecting past events but also shaping future events, and sometimes blurring the boundaries between what Thomas Turino has called presentational and participatory forms of music making. ${ }^{1}$

Sociologists of social movements in the U.S. such as Willam Roy, Serge Denisoff, Ron Ayerman, and Andrew Jamison have all pointed to the crucial role that collective music-making played during earlier political movements in the U.S., particularly the labor movement starting in the 1920s and in the struggle for Civil Rights. Nonetheless, while celebrating the power of collective music making to organize, galvanize, invigorate, and otherwise contribute to the health and efficacy of these movements, these scholars express pessimism about the potential for contemporary social movements in the U.S. to harness collective song in the same way. Among other obstacles, they point to the predominance of the hegemonic commercial music industry, the declining popularity of other forms of community music-making such as hymn singing in mainline Presbyterian churches, and the increasing prevalence of passive and isolating technologies of music consumption as factors that make collective music-making unlikely to be an important component of contemporary American social movements. ${ }^{2}$

The prominent and sustaining role that music played in the Wisconsin Uprising suggests otherwise; this case study demonstrates that contemporary American social movements' capacity for and interest in music making merit serious reconsideration. So too, I believe, does the changing role of mediation and mass-dissemination of music in response to changing technologies and technocultures. In order to address

\footnotetext{
${ }^{1}$ Music as Social Life: The Politics of Participation (Chicago: University of Chicago Press, 2008).

${ }^{2}$ Ron Eyerman and Andrew Jamison, Music and Social Movements: Mobilizing Traditions in the Twentieth Century (Cambridge, UK: Cambridge University Press, 1998); R. Serge Denisoff, Sing a Song of Social Significance (Bowling Green State University Popular Press, 1983); William G. Roy, Reds, Whites, and Blues: Social Movements, Folk Music, and Race in the United States (Princeton University Press, 2010).
} 
these issues, this article explores the ways that protesters in Wisconsin created, mediated, and remediated soundscapes of popular protest that invoked the historical imagination while forging new contemporary political-regional identities through sonic performance in public spaces. I propose a brief typology of three nodes of interaction in these cycles of live, mediated, and remediated sonic performance: the hypermediated narrative, the "virtual hootenanny," and the encoding of live presence within recorded media. In each of these nodes, live sonic performances and their mediated and remediated iterations are cyclically and symbiotically interrelated. Technologies of recording and mass dissemination do not preclude or replace live protests, but rather reflect them, supplement them, and sometimes shape them.

\section{Mass-mediated protest song and its discontents}

The year 2011 saw the emergence of some of the largest, most visible, and most sustained protest movements in the United States since the Vietnam War. Manifestations such as the Occupy movement, both on Wall Street and in related events nationally, and public protests in Indiana, Ohio, and Wisconsin over proposed legislation curtailing the rights of union members captured the attention of the press and the public. These movements were significant not only for the ways that they successfully brought populist politics to the center of public discourse, but also for the ways that they demonstrated the importance of the sonic elements of contemporary protest. One of the defining practices of the Occupy Wall Street protests was the use of the "people's microphone," a decidedly old-fashioned technique for amplifying speech through mass repetition that arose in response to regulations curtailing the use of amplified sound in Zuccotti Park. As several journalists and scholars have observed, the practice was successful not only because it was a clever pragmatic solution to a practical difficulty but also because it was a powerful symbolic performance of solidarity, a bodily enactment of a unified purpose. ${ }^{3}$

Nonetheless, one of the most pervasive observations about sound in the early days of the Occupy movement involved not the sounds that were present at Zuccotti Park but rather what many commentators and sympathizers felt was missing: a new repertoire of protest songs. "Every successful movement has a sound track," Rage Against the Machine guitarist and Occupy supporter Tom Morello told reporters in October of 2011. New York Times reporter James McKinley echoed his concerns the following week:

Musicians living through the greatest economic disaster since the Great Depression have largely filled the airwaves with songs about dancing, not the worries of the working people. Where have all the protest songs gone? ${ }^{4}$

The notion that an effective protest movement means effective protest music-and original protest music, at that, popular and widespread enough to "fill the airwaves" - is an attractive one, and one that may have particular resonance for the younger generations of Americans whose primary experience of protest movements has been, until recently, limited mainly to the consumption of mediated narratives of

\footnotetext{
${ }^{3}$ See, for example, Homay King, “Antiphon: Notes on The People's Microphone,” Journal of Popular Music Studies 24, no. 2 (2012): 238-46; Richard Kim, "We Are All Human Microphones Now," The Nation, October 3, 2011, http://www.thenation.com/blog/163767/we-are-all-human-microphones-now; Ted Sammons, “I Didn't Say Look; I Said Listen': The People's Microphone, \#OWS, and Beyond," Sounding Out!, November 21, 2011, http://soundstudiesblog.com/2011/11/21/i-didnt-say-look-i-said-listen-the-peoples-microphone-ows-and-beyond/.

${ }^{4}$ James McKinley Jr., “At the Protests, the Message Lacks a Melody,” New York Times, October 18, 2011.
} 
the Civil Rights and anti-Vietnam War movements and their attendant soundtracks. ${ }^{5}$ In fact, it is striking that both Morello and McKinley point not to live protest music but rather to its expression in massmediated forms ("sound track[s]" and "the airwaves," respectively) as the central indicator of the vitality of a protest movement. Real protest movements have original protest music, they argue, and real protest music gets recorded, it gets played on radio stations, and it makes good accompaniment to video.

In fact, music was central to some of the most important and effective American social movements of the nineteenth and twentieth centuries, from the abolition movement to the labor union movement of the 1920s to the movements in support of Civil Rights and against the Vietnam War in the 1950s and 1960s. Participatory music making in these movements was not just a consequence of members' preexisting interests or abilities; rather, many of these "singing movements" actively trained their members in group song and cultivated a shared repertoire of protest music. The Industrial Workers of the World (the "Wobblies"), for example, published thirty-seven editions of their "Little Red Songbooks," pamphlets of political song parodies, which they distributed among their members. ${ }^{6}$ Other movements provided participants with more direct musical instruction. Members of socialist and socialist-sympathizing groups like the Almanac Singers in the 1930s hosted regular "hootenannies," gatherings in which urban leftists shared their repertoire of new and old folk, jazz, and popular songs repurposed with new lyrics. ${ }^{7}$ The Highlander Folk School was instrumental in reviving and adapting black gospel songs for the Civil Rights movement, generating a "canon of freedom songs" and even leading a series of "Sing for Freedom" workshops in 1960 in order to train song leaders and choir directors to lead group song at meetings, vigils, and other movement events. ${ }^{8}$

While many of the songs associated with these movements were recorded, and some even enjoyed a degree of commercial popularity, it is important to recognize that the music of these social movements was created primarily for group performance, not for commercial radio play. In fact, groups such as the Almanac Singers even rejected offers to perform on the radio over concerns about censorship and the risk of compromising the movement's message. ${ }^{9}$ Even during the protest movement against the Vietnam War, there was less overlap between the antiwar songs that garnered significant commercial airplay and the songs that were central to the protest movement; R. Serge Denisoff reports that the only song that rose to prominence in both contexts was John Lennon's "Give Peace a Chance." 10

In fact, while contemporary activists and journalists writing about Occupy Wall Street may lament the lack of contemporary protest song on the airwaves, scholars of these historical movements have been far more skeptical about the potential for mass-mediated popular music to play a meaningful role within

\footnotetext{
${ }^{5}$ Both of these movements produced popular songs that achieved a degree of commercial success and staying power that makes them easily recognizable indices of the movements; one could point to folk revival ballads like Bob Dylan's "Blowin' In the Wind" and Pete Seeger's "Where Have All the Flowers Gone?" as well as rock anthems like Creedence Clearwater Revival's "Fortunate Son." Nonetheless, it is worth remembering that in both cases (but particularly the Civil Rights movement, with its repertoire of "freedom songs") the songs that were most important to the protesters themselves were not these popular tunes. That is, the mass-mediated "soundtrack" that is most associated with these movements was never the most important part of these movements' musical forms of protest. See, for instance, Ron Eyerman and Andrew Jamison, "Social Movements and Cultural Transformation: Popular Music in the 1960s," Media, Culture \& Society 17 (1995): 449-68; Kerran L. Sanger, “When the Spirit Says Sing!” The Role of Freedom Songs in the Civil Rights Movement (New York: Garland Publishing, Inc., 1995); Denisoff, Sing a Song of Social Significance.

${ }^{6}$ Ronald D. Cohen, Work and Sing: A History of Occupational and Labor Union Songs in the United States (Crockett, CA: Carquinez Press, 2010), 20.

${ }^{7}$ Eyerman and Jamison, Music and Social Movements, 66.

${ }^{8}$ Roy, Reds, Whites, and Blues, 169.

${ }^{9}$ Denisoff, Sing a Song of Social Significance, 104-05.

${ }^{10}$ Ibid., 38.
} 
contemporary U.S. social movements. Denisoff, arguing that the medium of popular music can only serve as entertainment, even suggests that "it may be useful to consider the notion that popular songs, by their very nature, cannot be protest songs." Sociologist William Roy, on the other hand, argues that it is not mass mediation itself that limits the potential use value of popular music, but rather that practices of passively consuming mass-mediated music have effectively supplanted earlier practices of participatory music making, leaving younger generations of Americans without the necessary musical skills to sing and play music together. ${ }^{12}$ Bloodgood and Deane have reported that technologies of music consumption like the Walkman and the MP3 player have increasingly encouraged isolation and individualization in social patterns of music listening, leading music consumers ever further from the "experience [of] singing of songs as a collective." 13

The case of the Wisconsin Uprising suggests that such pessimism may be misplaced or overstated. In fact, one of the most iconic musical practices of the movement, the Solidarity Sing Along, is nothing if not the "experience of songs as a collective," where participants gather each weekday to sing songs protesting Walker and his policies in the rotunda of the state capitol building. No mere musical gathering, the Sing Along has become such a salient and persistent ritual that the Walker administration and Sing Along participants have become embroiled in a lengthy and ongoing (as of this article's completion) legal battle over the legality of the event. In what many observers suspect to have been direct response to the Sing Along, in the summer of 2012 the administration enacted emergency rules requiring permits for gatherings of more than four people in the state house. ${ }^{14}$ Singers were arrested, and subsequently they challenged the constitutionality of the rules, setting up a series of confrontations in the capitol and in the courts that attracted the attention of the national press and the ACLU, and swelling the dwindling number of participants in the Sing Alongs. ${ }^{15}$ Whether the legality of the arrests ultimately stands or not, one thing is clear: in contemporary political protest in Wisconsin, making music still matters.

Nonetheless, as Denisoff or Roy might have anticipated, little of the music of the Wisconsin Uprising made it to the airwaves in any meaningful way. Technologies of mass mediation and mass dissemination played key roles in shaping the soundscapes of this movement, but they were largely used outside of the commercial music industry. The pervasiveness of relatively high-quality technology for sound and video production, and of digital infrastructures such as social media platforms, made grassroots forms of mediation and remediation an organic extension of the other forms of popular organization and speech for many protesters. The particular geographical, political, social, economic, and cultural context in which this movement took shape was, of course, fundamental to these processes.

\section{Setting the stage for a protest movement}

On February 15, 2011, the Wisconsin State Assembly, at the request of newly elected Republican governor Scott Walker, introduced Assembly Bill 11, Walker's "Budget Repair Bill," which proposed

\footnotetext{
${ }^{11}$ Ibid., 39.

${ }^{12}$ Roy, Reds, Whites, and Blues, 248.

${ }^{13}$ Elizabeth Bloodgood and Shelley Deane, "Where Have All the Protest Songs Gone? Social Movements' Message and Their Voice in Politics" (presented at the Annual Meeting of the American Political Science Association, Washington D.C., 2005).

${ }^{14}$ Andrew Averill, "Solidarity Sing Along to Test New Wisconsin Capitol Access Rules and Not Apply for Permit," Isthmus, December 14, 2011, http://www.thedailypage.com/daily/article.php?article $=35440$.

${ }^{15}$ Judith Davidoff, “Solidarity Sing Along Protest 'Fueled' by Wisconsin Capitol Pollice Crackdown,” Isthmus, August 22, 2013, http://www.thedailypage.com/isthmus/article.php?article $=40711$.
} 
substantial cuts to major portions of the state budget, including education, the Department of Natural Resources, Medicaid and other social support programs. While these cuts were largely anticipated based on the governor's campaign platform, the legislation also introduced a series of unannounced cuts to public sector employees' pension and insurance programs. Even more significantly, the bill proposed limiting public sector unions' negotiating and organizing power, eliminating collective bargaining rights and their ability to collect dues through payroll deduction. ${ }^{16}$ Despite the far-reaching implications of the proposed legislation, Governor Walker urged lawmakers to act quickly on the bill, originally requesting that it be voted on no later than February 25. In fact, prior to the protests, committee hearings and a floor vote were already being scheduled for the week following Governor Walker's preliminary announcement of the bill. $^{17}$

The public sector unions and their supporters mobilized in response nearly immediately, and on a scale that would ultimately surpass the local records for public protest of any kind, surprising many commentators. ${ }^{18}$ On the Tuesday that the bill was first introduced, one local reporter described the crowd, estimated at 12,000, as "one of the largest protests in recent memory." 19 The ranks continued to grow throughout the week; 30,000 protesters found their way to the Capitol the following day, and 25,000 the day after that. The first weekend of the protests drew many participants to Madison from other parts of the state and beyond, and police estimated that the crowds numbered between 70,000 and 100,000 that Saturday. ${ }^{20}$

Legislators opposing the bill were no slower to act. Knowing that the Republican majorities in both houses virtually assured the bill's passage with only a minimum of public debate, on Thursday, February 17, the fourteen Democratic members of the state Senate chose to abruptly leave the state for an undisclosed location (Rockford, Illinois, as it turned out) to prevent their Republican counterparts from attaining the necessary quorum to vote on the bill. ${ }^{21}$

The ensuing weeks were a time of intense public debate and political gamesmanship in which lawmakers from both parties relied on highly unusual maneuvers that seemed at times to be a combination of bureaucratic rule manipulation and political theatre. Following the Democratic senators' exit, the governor dispatched the state patrol to search for and forcibly return them to the deliberative chamber, although the lawmakers were not discovered until safely across the Illinois border and beyond the

\footnotetext{
${ }^{16}$ Committee on Assembly Organization, Assembly Bill 11, 2011, http://docs.legis.wisconsin.gov/2011/related/proposals/jr1_ab11.pdf.

${ }^{17}$ Jason Stein and Patrick Marley, "Walker Calls for Cuts or Big Layoffs," Milwaukee Journal-Sentinel, February 11, 2011, http://www.jsonline.com/news/statepolitics/115911379.html.

${ }^{18}$ For a more detailed ethnographic account of the early weeks of the protests, see Jane Collins, “Theorizing Wisconsin's 2011 Protests: Community-Based Unionism Confronts Accumulation by Disposession,” American Ethnologist 39, no. 1 (2012): 620.

${ }^{19}$ Clay Barbour, “Thousands Gather at Capitol to Protest Walker Budget Bill,” Madison.com, February 16, 2011, http://host.madison.com/news/local/govt-and-politics/thousands-gather-at-capitol-to-protest-walker-budgetbill/article_de45ba12-3935-11e0-9b64-001cc4c002e0.html.

${ }^{20}$ Lila Shapiro, "Wisconsin Protests: State Police Pursue Democratic Lawmakers Boycotting Vote," Huffington Post, February 17, 2011, http://www.huffingtonpost.com/2011/02/17/wisconsin-protests-scott-walker-police_n_824697.html; "Upwards of 70,000 Rally at State Capitol," WKOW.com, February 19, 2011, http://www.wkow.com/Global/story.asp?S=14062370; Abby Sewell, "Protesters out in Force Nationwide to Oppose Wisconsin's Anti-Union Bill,” Los Angeles Times, February 26, 2011, http://articles.latimes.com/2011/feb/26/nation/la-nawisconsin-protests-20110227.

${ }^{21}$ Scott Bauer, "Wisconsin Lawmakers Flee State to Block Anti-Union Bill," Associated Press, February 17, 2011, http:/www.huffingtonpost.com/huff-wires/20110217/us-wisconsin-budget-unions/.
} 
Wisconsin police's jurisdiction. ${ }^{22}$ The Assembly ultimately passed the bill 51 to 17 when the Republican speaker abruptly called a voice vote and twenty-eight of the chamber's thirty-eight Democrats were unable to vote. ${ }^{23}$ The Democrats challenged the legality of that move in court, arguing that their opponents had violated the state's open meetings procedures. The county court agreed, and the case was appealed to the state's Supreme Court, which itself was in flux pending the results of a judicial election in April.

Ultimately, the Republicans would prevail, as the Supreme Court ruled in their favor and Walker's legislative agenda was eventually enacted largely unchanged. But the protracted, confusing and irregular process through which this happened was particularly conducive to sustained and intense public protests that continued, in varying degrees, through the year and into the beginning of 2012, when Governor Walker won by a narrow majority the special election in which he faced a potential midterm recall. These protests were carried out in person, in print, and online, and the musical and sonic components of those protests came to play a central role in all three of those spaces. But those roles were not immediately obvious or predetermined; rather, through participation and the use of media, participants came to construct and stake claim to a politically meaningful soundscape.

\section{Creating a sonic identity for a contemporary labor movement}

February 14, 2011: The Teaching Assistants' Association, a union of graduate student employees at the University of Wisconsin-Madison, leads the first march to the capitol building in protest of Governor Walker's proposed legislation. Holding signs that riff on the Valentine's Day date of the protest ("I love UW," “Governor Walker, don't break our heart") the group marches from campus to the capitol building. Along the way, numerous short group chants that will not gain traction during the following weeks are taken up ("Spread the love! Stop the hate! Don't let Walker legislate!"). Finally, the marchers stop outside the capitol entrance, where one union leader addresses his colleagues with a megaphone, reminding them of the tenor of the protest and organizing one group chant: "Remember, love in your hearts, leave the signs with the sticks out here, let's show Governor Walker that we will stand up for our university and the people that make it work. KILL THIS BILL! KILL THIS BILL!” Quickly, the several hundred protesters take up the chant, which booms against the marble walls of the capitol hallways as the union members file into the large capitol rotunda.

Video Example 1: Teaching Assistants’ Association enters the Capitol, February 14. (C) Emily Mills; used by permission.

View at: http://dx.doi.org/10.3998/mp.9460447.0007.204

February 19, 2011: It is the first weekend of the protests. Amidst the crowd, estimated at more than 70,000, I march around the square with my wife and our infant daughter in her stroller. When our daughter falls asleep, we escape to the warm lobby of the Madison Children's Museum. Just outside, I see

\footnotetext{
${ }^{22}$ Jay Sorgi, “Capitol Chaos: State Patrol Goes After Democratic Senators,” accessed March 20, 2013, http://www.todaystmj4.com/news/local/116469428.html.

${ }^{23}$ Nitasha Tiku, "Wisconsin Assembly Passes Anti-Union Bill in Late-Night Sneak Attack," New York Magazine, February 25, 2011, http://nymag.com/daily/intelligencer/2011/02/wisconsin_assemblys_sneaky_mov.html.
} 
a loosely assembled group of around a dozen people preparing a haphazard sort of musical ensemble. One holds a bass drum, another a trumpet, and several are helping each other safety-pin small red cloths silkscreened with a tuba emblem reading "FORWARD MARCHING BAND." One tall bearded man holds up a marching snare drum, and asks, "Does anyone know how to play this thing?" I step forward. A few moments later, I am harnessed in to the instrument, and we join the march around the square playing and singing alternately what we soon discover are the only two songs in our collective repertoire: "We Will Rock You" and "Solidarity Forever." In the latter case, many band members and other marchers join us in singing the chorus. Nobody seems to know any verses, so they are repeatedly played only by the clarinetist and trumpeter, before the chorus picks up again each time.

Wisconsin has a long history of pro-labor and progressive policies and activism. In 1959 it became the first state to establish collective bargaining rights for public sector workers, ${ }^{24}$ and the capital city of Madison, home of the University of Wisconsin-Madison, was a hotbed of resistance to the Vietnam War. Nonetheless, many of the younger generations of protesters at the capitol in February had only experienced this history indirectly through mediated narratives. Thus, while these protesters shared a desire for collective action with and through sound, at the beginning of this movement participants did not share a repertoire of familiar chants or songs through which to sound together. During the early days of the protests, I witnessed many events like those I describe above, in which participants tried, with varying degrees of success, to construct ways of creating collective sonic practices to accompany and shape the protest movement. Over the following months, some of these practices would become standardized and more broadly shared, while others were less enduring. Very little of this soundscape intersected with the commercial music industry; with the exception of local community-sponsored radio, most of this music was performed, disseminated and shared entirely off the airwaves. But mediation did frequently play an important role in the ways that these sonic practices developed, were shared, and accrued significance. In the following sections I describe three different nodes of interaction between the mediated and the live in the soundscapes of the Wisconsin uprising: hypermediated narration, the virtual hootenanny, and the encoding of live presence in recorded media.

\section{Hypermediated narratives}

Following Bolter and Grusin, I use the term "hypermedia" to describe forms of mediated experience that acknowledge the process of mediation itself..$^{25}$ Hypermediated experiences are not attempts to create a simulacrum of a live experience, but rather they seek to create a new experience, translated into a new medium and, on some level, about that new medium. This is not to say that hypermedia make no attempt at realism (although some, to be sure, do not); rather, that "the real is defined in terms of the viewer's experience; it is that which would evoke an immediate (and therefore authentic) emotional response." 26

In this case, the hypermedia that I wish to examine include a genre of videos that attempts to convey the emotional response of protest participants, using images and sound to convey a coherent dramatic

\footnotetext{
${ }^{24}$ Joseph Gyourko and Joseph Tracy, An Analysis of Public and Private Sector Wages Allowing for Endogenous Choices of Both Government and Union Status, Working Paper (National Bureau of Economic Research, May 1986), http://www.nber.org/papers/w1920.

${ }^{25}$ Jay David Bolter and Richard Grusin, Remediation: Understanding New Media (Cambridge, MA: MIT Press, 2000).

${ }^{26}$ Ibid., 53.
} 
narrative to the arc of developing events on the public scale while simultaneously rendering this narrative personal, individualized, and emotionally charged. These videos draw on both existing and original music, combined with still and moving images taken from the protests themselves. The widespread accessibility of digital video cameras, video editing software, and social video sharing platforms such as YouTube meant that homemade videos quickly became a prevalent mediated reflection of the protests.

One early example demonstrates the way that the genre effectively combines the immediacy of images of the protests themselves taken by protesters with a non-diegetic soundtrack that provides both narrative framing and a personalized emotional undercurrent to the events. On the first Saturday morning of the protests, long-time Madison-based singer and songwriter Ken Lonnquist appeared on community radio station WORT, performing live his song "Fourteen Senators," which he had written just an hour earlier. The driving, blues-inflected tune, with Lonnquist on guitar backed by a gritty fiddle, narrates the growing protest movement and lionizes the Democratic senators' decision to flee the state, preventing quorum:

Fourteen senators, sneakin' 'cross the border,

Fourteen senators, Capitol disorder,

Fourteen senators, new Wisconsin heroes.

What's the score? Senators fourteen,

Governor Walker zero!

2,000 Monday, 10,000 Tuesday,

15,000 Wednesday, 25,000 Thursday.

Walker won't listen to the people of his state,

Won't listen, won't bargain won't negotiate!

Video Example 2: Home-produced YouTube video for Ken Lonnquist's “14 Senators.” (C) Ken Lonnquist/ Bryan Hirsh; used by permission.

View at: http://dx.doi.org/10.3998/mp.9460447.0007.204

One listener, Bryan Hirsh, heard the performance and decided that the song merited a wider distribution than it was likely to receive from the low-wattage community radio station. Later that day, he downloaded an archived version of the performance from the radio station's website, and created a homemade video that synched Lonnquist's song with images from the weekend's protests, mainly wide-angle shots of large crowds of protesters assembled inside and outside of the capitol. Hirsh uploaded his creation to YouTube, where it began to attract attention well beyond the modest audience of the community radio station. Lonnquist himself had not been involved with, or even aware of the video's production. "It was the next morning [after the radio performance] that someone sent me an e-mail saying 'I love the video,' and I had no idea what they were talking about," he later told me. "And I went to the link, and it already had about 400 hits!"27 Within a week, the video had received over 38,000 views. Although I was not able to obtain reliable data on audience sizes, this number suggests that it is likely that the video's reach far exceeded that of either the community radio broadcast or the studio recording that Lonnquist released independently on $\mathrm{CD}$ the following month.

${ }^{27}$ Lonnquist, personal communication. 2012. 
This genre of videos seems to serve two complementary purposes. First, they provide an intensifying and unifying emotional narrative, shaping the collective memory of participants who view events that they themselves participated in. Many of these videos use a combination of visual and sonic elements in a way that conveys the scope of the protests (in some cases, using Hollywood-esque soundtracks to lend the events a quasi-cinematic grandeur) but in an affective register that is at times intensely personal. In this case, the video combines macroscopic visual representations of the event including panoramic and even aerial photographs of the crowds with the intimacy of a close-miked and nearly conversational vocal style and a rough-edged performance that conveys all the urgency of the need to comment on an event that is mere hours old. Second, protesters recirculated these videos through social media not only as an affirmation or celebration of past events, but also as an entreaty of solidarity encouraging sympathizers to participate in the movement. For example, during the campaign to collect signatures on petitions to initiate recall elections, and later in the days leading up to the signature collection campaign and the recall elections themselves, ${ }^{28}$ many of these videos began to recirculate as protesters and others reposted them to social networks as a way to link the emotional intensity of those early weeks with a current call to action.

\section{The virtual hootenanny}

One of the most striking applications of technologies of mediation in this movement has been the use of hypermedia and virtual spaces to encourage and even shape future live participation in protest events. Musicians and activists used Internet distribution of audio and video recordings, lyric and chord sheets, and online forums where participants collectively composed lyrics and discussed group repertoire, making decisions in virtual space that would then shape the sound and practices of future live protests.

While some of these technologies (home digital and audio production software, Web-based distribution of audio files, social media) are relatively new, their use in this movement is in a sense a solution to an old problem, and one more point in a long history of American "singing movements" collectively creating their own soundtracks. The American labor movement of the first decades of the twentieth century used printed song pamphlets and social gatherings like hootenannies to construct and consolidate the repertoire and musical practices of their movement. Similarly, the musicians and activists leading the protests of the Wisconsin Uprising deployed these new technologies in ways that served as a kind of virtual hootenanny, convening in virtual spaces and relying on recordings and digital distribution not only to attract sympathizers, but also to guide participants.

Here, I explore these processes through the analysis of two prominent actors in this network: the Madison-based Irish band the Kissers_and particularly the viral success of their protest anthem "Scotty, We're Coming For You!" - and the most visible and sustained of the musical protest groups, the Solidarity Sing Along. The creation of this song, and its later adoption by the Sing Along are a compelling example of the processes of creation, mediation, dissemination and remediation, and their relation to these new technologies. "Scotty, We're Coming For You!" is, in some ways, an archetypal protest anthem; it is a feisty Irish-folk-inflected number in a rollicking 6/8 meter with a cathartic, shouted chorus that practically

\footnotetext{
${ }^{28}$ The debate over the budget and collective bargaining legislation galvanized and polarized the electorate, and extensive petition drives led to sixteen senators (eight from each party) facing midterm recall elections in August of 2011. Governor Walker faced a similar challenge nearly a year later (the state constitution prevented his opponents from filing a recall petition within the first year of his term). Ultimately, Walker won the recall election against his challenger Tom Barrett in June of 2012.
} 
demands audience participation. In fact, the song's author, bassist and singer Ken Fitzsimmons of the Kissers, told me that he wrote it specifically "hoping that it would become an anthem ... and that anybody could have a copy or play the song that wanted to." ${ }^{29}$ He recalled the sense of urgency which led quickly from the song's genesis to its first emergence on the Internet, in a video posted to the band's own website. Fitzsimmons wrote the song the morning of March 15, when his band was scheduled to perform in a St. Patrick's Day parade, "and [I] threw down the lyric sheet and [we] played it in the parade, like three times, and went home that night and fiddled with a few lines, and then the next night we were recording a live show ... [In the YouTube video] you can still see me looking down at the lyrics sheet on the table." ${ }^{~}{ }^{0}$ The band uploaded the video of the performance to YouTube that same evening, which they linked on their website, where they also posted MP3 files and play-along lyric and chord sheets for download by fellow protesters.

Video Example 3: The Kissers, "Scotty, We're Coming For You." (c) Ken Fitzsimmons; used by permission.

View at: http://dx.doi.org/10.3998/mp.9460447.0007.204

The video itself attracted relatively little attention from Internet audiences, garnering slightly less than five thousand plays in the first six months of its existence. But this low number belies the song's impact within the protest movement. For the Kissers, the video and audio recordings of this song were not conceived as an end in themselves, but rather a means toward encouraging the spread of the song as a participatory act. In this regard, "Scotty, We're Coming for You" has been far more successful: the song quickly became a mainstay of the Solidarity Sing Alongs (one of few songs with original melodies to do so), where many days it is likely that the eponymous Scotty heard the chorus shouted from the rotunda below his capitol office. The memorable chorus phrase even made its way onto Sing Along banners that the singers draped from the second floor of the capitol during the noon events. More significantly, the song even drew attention from politicians themselves. In the late spring of 2011, the campaign of one Democratic challenger to a Republican senator facing recall, recognizing the motivational potential of the chorus's catchy and memorable call to action, asked Fitzsimmons to record a new version, substituting the incumbent's name for the governor's. The Kissers agreed and quickly recorded and uploaded to their website for free download versions with customized choruses for each of the Republican legislators being recalled ("Danny [Kapanke] We're Coming For You," "Alberta [Darling] We're Coming For You," etc.). In effect, they created what Almanac Singer Lee Hays called a "zipper song," where singers "only have to zip in a word or two to make an entirely new verse." 31

No group in the Wisconsin protest movement has used music in as sustained or as public a way as the Solidarity Sing Along, a loosely organized, grassroots group who have gathered daily in the Capitol rotunda to sing anti-Walker and pro-labor songs. ${ }^{32}$ While the group does include a core membership of approximately two dozen individuals who attend on a weekly to daily basis, the sing-alongs often involve a

\footnotetext{
${ }^{29}$ Fitzsimmons, personal communication, 2011.

${ }^{30}$ Ibid.

${ }^{31}$ Doris Willens, Lonesome Traveler: The Life of Lee Hays (U of Nebraska Press, 1988), 57.

${ }^{32}$ As of the drafting of this article, there have been over five hundred Sing Along events, and the group is ongoing and its membership evolving. The description of the group here is mostly based on field research undertaken between March and August of 2011.
} 


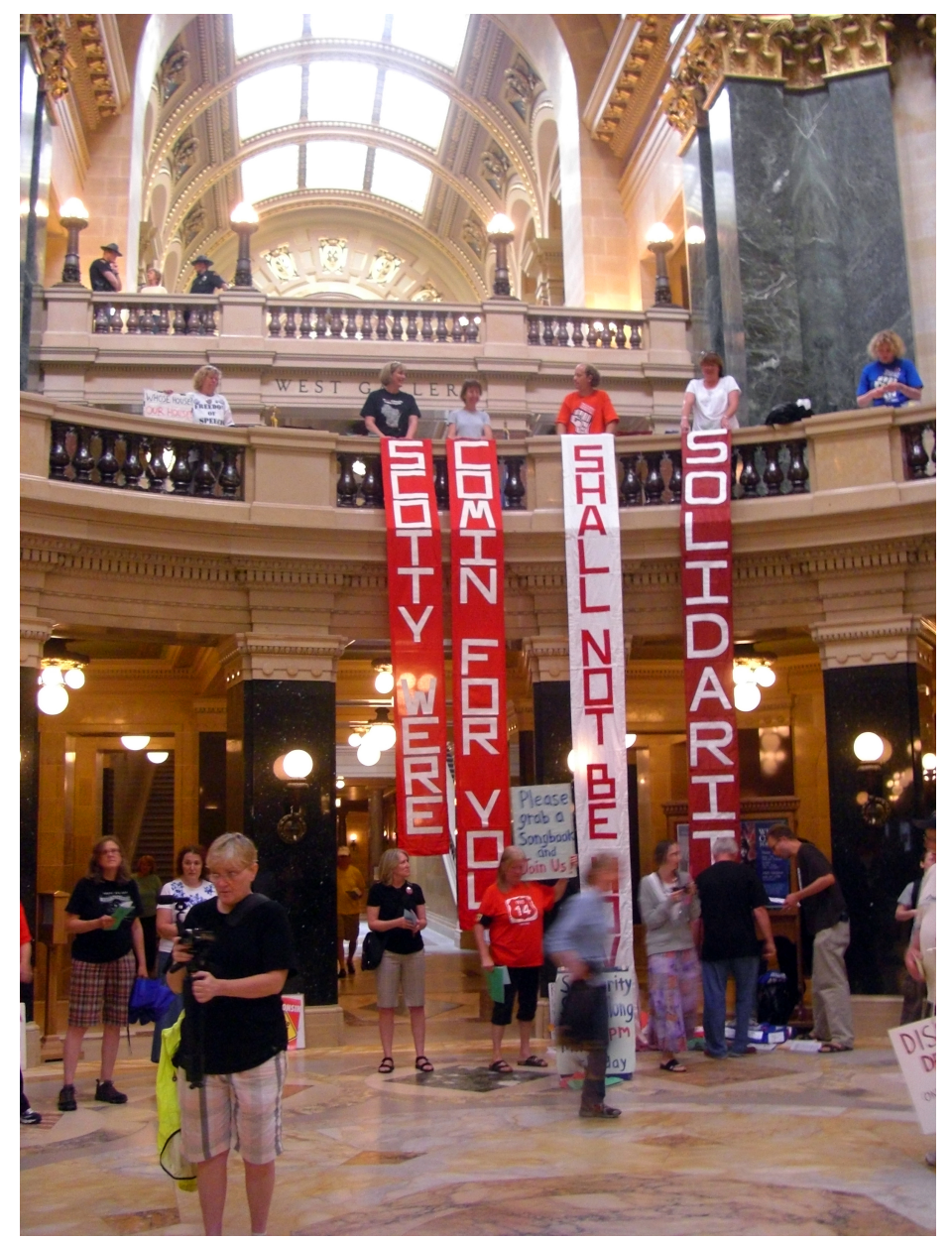

Figure 1: Banners at a Solidarity Sing-Along. (C) Chris Patterson; used by permission.

substantially larger population of casual or occasional participants. Most weekdays during the first year of the group's existence, between eighty and one hundred singers showed up, while for anniversary events and other milestones, or in response to particular pieces of political news, single-day attendance reached several hundred. Sing Along participants have been quick to correct journalists who have portrayed them as the "Solidarity Singers," insisting instead on the term "Sing Along," to emphasize that they are not a defined group but rather individuals who coalesce as part of a public event.

The first Solidarity Sing Along was held on March 11, 2011, led by Steve Burns, a teacher at a local community college and activist with the Wisconsin Network for Peace and Justice. Burns and the WNPJ originally planned to hold a weeklong series of daily sing-alongs that conveniently coincided with spring break for the community college and Madison public schools, capitalizing on the large number of the protest participants who were school employees. There was enough interest in the sing-alongs, however, that when Burns' own teaching schedule precluded him from continuing to organize, he passed responsibilities to R. Chris Reeder, a then-underemployed Shakespearian actor who had been a regular participant. Reeder, who has no formal musical training, then served as organizer and de facto spokesperson for the group until June of 2012.

Typically, Reeder and other participants congregated in the rotunda of the state capitol building, forming a large circle. They provided photocopied songbooks with lyrics, containing a variety of songs 
drawn from the U.S. labor and civil rights movements as well as a few original songs (including "Scotty, We're Coming For You!") and songs that set existing folk and popular melodies to new lyrics. Reeder frequently chose the order of the songs for the day, based on participants' requests and the group's response to songs that had been presented in earlier sing-alongs. In performance, the group's singing tended to replicate the social dynamics that brought the group together-a few close and enthusiastic individuals would instigate a call that then grew in strength and coherence through accretion as other participants joined in.

Audio Example 1: Field recording of a Solidarity Sing Along, July 2011.

View at: http://dx.doi.org/10.3998/mp.9460447.0007.204

There are substantial challenges involved in creating and maintaining a coherent sonic and social identity for the Sing Along. By framing it as an event rather than a group, the Sing Along's creators sought to create as open and democratic an institution as possible, to encourage maximum participation regardless of singers' commitment or experience. This approach mirrors those of community-based theatrical troupes such as the ones Jan Cohen-Cruz writes about, in that its open structure provides an opportunity for all engaged citizens to perform what Cohen-Cruz has called "participatory cultural democracy." There are compelling reasons why this approach makes for effective political speech; the act of independent citizens coalescing daily in the hall of government in a non-hierarchical and essentially leaderless act of collective speech and solidarity is a striking enactment of what J. L. Austin has called a "performative utterance," a kind of speech that "actualizes what it invokes." ${ }^{34}$ Judith Butler has drawn attention to the ritualistic character of these utterances, which contain a "condensed historicity" in which any individual performance invokes both past and future iterations of the performance event. ${ }^{35}$ In this case, the Sing Along draws upon a repertoire of classic songs from the American labor movement ("Solidarity Forever," "Which Side Are You On?," "Union Maid") as well as new songs that include calls to action and anticipate a Walker-less future (“Scotty, We're Coming For You”).

The same openness and horizontal organization that make the Sing Along such an effective performance of its democratic ideals also complicate the task of creating and sustaining a musically coherent identity for the group. This is particularly true given the group's interest not only in drawing from the existing protest song tradition but also in creating new lyrics and even new songs that speak specifically to the Wisconsin situation. Since the group never meets to rehearse outside of their noontime events and the membership is so loosely structured, the group has heavily relied on social media in order to create and maintain musical and social coherence. Specifically, the Sing Along's Facebook page became an important space for collective action, where participants shared opinions about the group's repertoire, shared video and audio clips to songs that they might like to adapt or perform and even engaged collectively in composing new lyrics. Figure 2 shows one representative example, in which the group members are discussing possible lyrics for a Christmas edition of their songbook. The page's administrator, Chris Reeder, proposes a set of verses for a contrafactum of "O Tannembaum," and another

\footnotetext{
${ }^{33}$ Jan Cohen-Cruz, "The Problem Democracy Is Supposed to Solve: The Politics of Community-Based Performance," in The Sage Hanbook of Performance Studies (Thousand Oaks, CA: Sage Publications, 2006), 432.

${ }^{34}$ This observation is indebted to King's analysis of the human microphone in "Antiphon."

${ }^{35}$ Judith Butler, Excitable Speech: A Politics of the Performative (New York: Routledge, 1997), 3.
} 
member contributes several verses of her own. Over the course of the succeeding days, group members express preference for some verses, and after various songs are tried at Sing Alongs, those that meet with the greatest degree of crowd participation and approval are assembled into a printed holiday songbook.

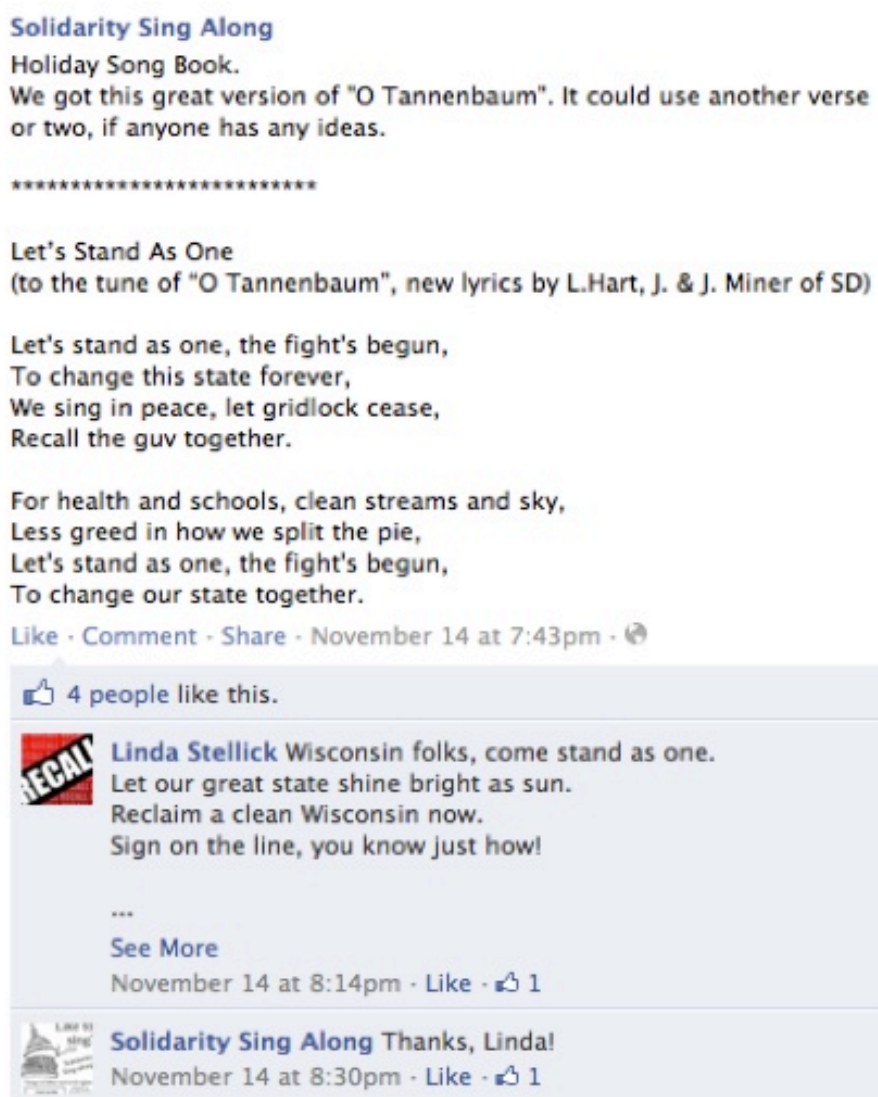

Figure 2: Solidarity Sing Along participants collectively composing lyrics via the group's Facebook page.

\section{Encoding of live presence in recorded media}

While groups like the Kissers and the Solidarity Sing Along used mediation as a strategy to shape live performances, these flows were not unidirectional. Rather, there were also instances in which musicians and others sought to encode their own presence at the protests into recorded media. The simplest of these consist of raw video and audio footage from protest events around the state, which creators often shared as a way to offer a virtual firsthand account of the experience to far-flung friends, relatives, and interested observers.

Many protesters expressed frustration with the limited or skewed way that the events were portrayed in the commercial media, and saw these forms of eyewitness mediation as a genre of grassroots counternarrative to contest those being generated in the news media. Fox News was a particularly common target of the protesters' derision, especially following an episode of the program The O'Reilly Factor, which juxtaposed old B-roll footage of contentious union protests in a warmer clime (sharp eyes noted the incongruous palm trees in the background) during a story on the Wisconsin protests in 
February, obliquely suggesting, although not explicitly claiming, that the images represented the current state of affairs in the northern state. ${ }^{36}$ The unreliability of the news media, and Fox News in particular, even became a subject of the protests itself, when protesters posed amidst inflatable palm trees sporting anti-Fox News slogans in a parodic, remediated performance of the media's own unreliability (Figure 3 ). Homemade video and audio of protest events stressing their peaceful and even family-friendly nature served as powerful counternarratives, and circulated virtually through social networks. "I told my dad, who lives in Arizona," one protester told me, "if you really want to see what's going on, don't turn on the news, go to Facebook."

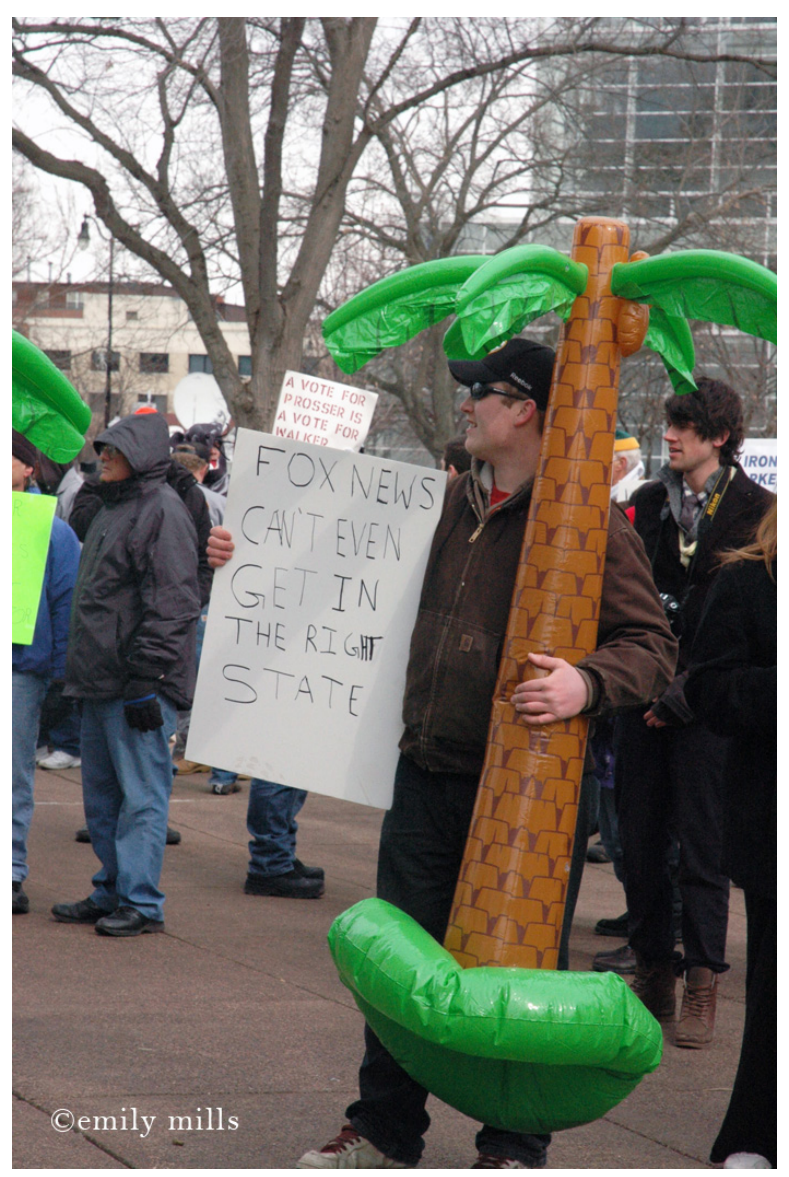

Figure 3: Protester with inflatable palm trees. (C) Emily Mills; used by permission.

A more complicated and singular case in which the soundscapes of the protest were transferred to a mediated experience involves a sort of genetic transfer of sonic codes of live participation into presentational media. At the beginning of the protest movement, as I noted above, protesters needed guidance and instruction in group chants as there was not yet an established shared repertoire of codes of public participation. While many speakers, bolstered by sonic amplification, led a wide variety of group chants, some were more successful than others. Soon a sort of canon of favorites became prevalent; the aforementioned "Kill the bill" was quite popular in the early weeks, until the bill in question was actually passed. By far the most enduring chant, however, was one that did not originate in Wisconsin but dates

\footnotetext{
${ }^{36}$ Jon Ponder, "Did Fox Mean to Deceive with 'Palm Tree Lie' - Or Were O’Reilly's Producers Just Being Sloppy?,” Pensito Review, March 2, 2011. http://www.pensitoreview.com/2011/03/02/fox-video-of-angry-wisconsin-protesters-shows-palm-trees/.
} 
back to at least the protests against the World Trade Organization in Seattle in $2000 .^{37}$ It's a simple call and response chant with just enough syncopation to be rhythmically interesting and distinctive.
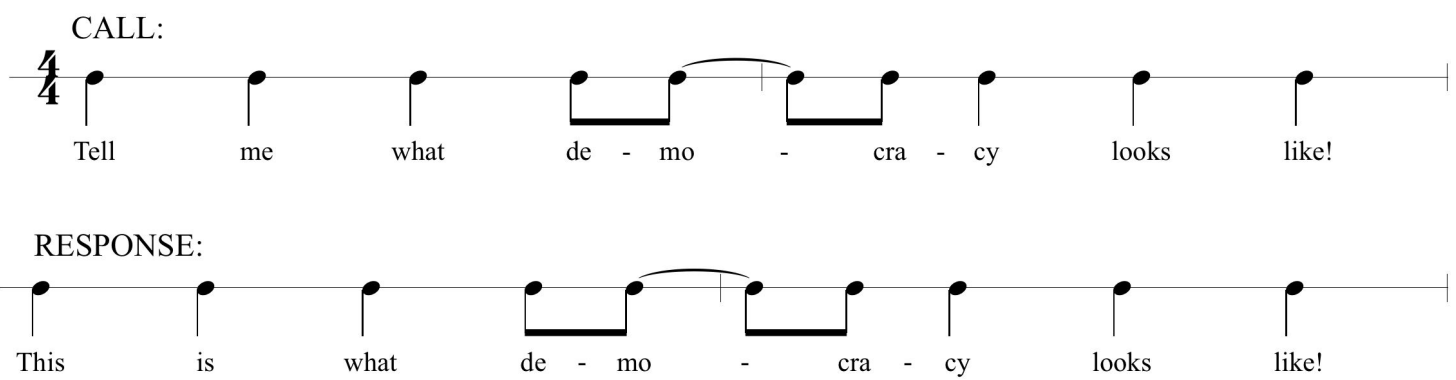

Figure 4: "This is what democracy looks like!" protest chant.

This rhythmic distinctiveness allowed for this chant to be transmitted nonverbally as well. For several hours following the passage of the bill curtailing collective bargaining on March 8, an event that transpired abruptly and without the presence of the Democratic senators, hundreds of cars drove in circles around the state capitol, their horns blaring in overlapping repetitions of the rhythm in a practice some locals would come to call the "democrabeep."

Video Example 4: Cars honking “democrabeep” rhythm, March 2011. (C) Jacquelyn Gill; used by permission. View at: http://dx.doi.org/10.3998/mp.9460447.0007.204

Isolated instances of automobile democrabeeping continued in and around Madison for several months, becoming an efficient way for drivers passing by the protests to telegraph their solidarity and ingroup knowledge with protesters. I also was told of a high school band teacher who used the rhythm in warm-up scales with his band class, trading knowing looks with a few of the students who had been active in the protests but otherwise leaving the coded message of presence and solidarity unspoken.

Professional musical groups, too, have latched onto the rhythm and sometimes the accompanying chant, encoding their own presence at the protests into presentational musical performances, which are then in turn recorded and distributed through digital means. One Madison-based blues band, Bonobo Secret Handshake, began their "Scott Walker Blues" with the rhythm, first playing it alone on cowbell and then gradually thickening the groove by adding the rest of the rhythm section, before revealing the lyrics in a call-and-response setting.

Video Example 5: Bonobo Secret Handshake, "Scott Walker Blues." (c) Bonobo Secret Handshake, used by Creative Commons Attribution-ShareAlike 3.0 license.

View at: http://dx.doi.org/10.3998/mp.9460447.0007.204

\footnotetext{
${ }^{37}$ David Graeber, Fragments of an Anarchist Anthropology, 1st ed. (Prickly Paradigm Press, 2004), 84.
} 
This remediation of protest soundscapes does not depend on insider knowledge to be intelligible; the lyrics are ultimately revealed, and the song's message is clear enough even to a listener who may not associate the rhythmic phrase with the protests themselves. Nonetheless, this transfer of paralinguistic rhythmic practices functions, in semiotic terms, as an index ${ }^{38}$ of the protests themselves, encoding in the song's affective register a sense of the musicians' own presence and participation in that protest movement. The song is not just about the Wisconsin Uprising but in fact sonically contains it. "Scott Walker Blues" is not a protest song in the conventional sense: it was not meant to be performed as a mass song at protest events, and its electric blues/funk aesthetic is certainly a departure from the folk-rock conventions of late twentieth-century American protest music. Nonetheless, it is a song whose value and meaning are intensified by the way that it sonically encodes the soundscapes of the protests within a remediated musical performance.

\section{Conclusion}

The experiences of the Wisconsin Uprising strongly suggest that participatory music making can remain a meaningful and effective practice in contemporary American social movements. Furthermore, these participatory forms of music making need not be, as Denisoff and Roy have suggested, endangered by or even precluded by mass mediation and passive consumption of music. Rather, in this case the mediated, live, and remediated soundscapes of the movement were mutually and often beneficially intertwined. Nonetheless, I think it is worth questioning how representative or repeatable a phenomenon like the music of the Wisconsin Uprising might be.

There are several ways in which the Uprising was atypical of contemporary social movements, ways that facilitated the centrality of music making to the movement but might be difficult to replicate in other circumstances. First is the issue of geography and space. Participatory music making requires co-presence, and unlike many of the social movements that Roy identifies as unlikely to adopt practices of collective song (the gay rights, antiwar, and environmentalist movements, for example), the Wisconsin Uprising was geographically limited in scope and had, in the state capital, a logical and convenient physical nexus in which to coalesce; its issues were fundamentally local rather than global. Madison in general, and the state capitol building in particular, provided an especially fortuitous space for a singing movement. The symbolic potency of political speech in direct proximity to the people and institutions they critiqued, coupled with the acoustic potency of the resonant, almost cathedral-like architecture, made the capitol perhaps the ideal space for the act of group song as political protest.

Second, the anti-Walker movement was unusual in the context of American social movements in that it is, in a way, conservative and backward-looking. It was not, of course, conservative in the sense of political ideology but rather in that, unlike earlier manifestations of the labor movement or the civil rights movement in which participants were calling for a fundamental reimagining of the structures of political power and social order, the anti-Walker movement's vision was decidedly more circumspect. They argued not for transformation but for restoration of the social and political values that they argue have been one of the fundamental aspects of the Wisconsin political system and Wisconsin's social identity. This discourse, in which Walker's policies represent a rupture from and assault on the historically stable and functional

\footnotetext{
${ }^{38}$ Thomas Turino, "Signs of Imagination, Identity, and Experience: A Peircian Semiotic Theory for Music," Ethnomusicology 43, no. 2 (1999): 221-55.
} 
system of broad social support for public sector workers and institutions, is one that is particularly wellsuited to musical practices and repertoires that perform the history of the labor rights movement as a living tradition. When the Solidarity Singers chose to revive and update songs and practices from the history of the labor movement, they were staking a claim to that history that made it sonically a part of the present discourse as well. Social movements whose goals were less tied to a restoration of a preexisting social order would have less motivation to reconstruct these historical texts and practices.

Nonetheless, the Solidarity Sing Along in particular and the soundscape of the Wisconsin Uprising in general do suggest that, at the very least, protest music can still form an important component to contemporary social movements. Furthermore, oppositional dichotomies between the live and the mediated, between the presentational and the participatory, and between music that is passively consumed in isolation and music that is communally created are perhaps overstated. Viral video, web distribution of audio files, and collective composition through social media all served to facilitate future live participatory music making. In turn, musicians even began to sonically encode the live protest experience within traditionally presentational media for passive consumption. The protest song may have gone from the airwaves, but it is not entirely gone.

\section{Acknowledgments}

I am indebted to all of the protest participants and musicians whose interviews helped shape my understanding of the Wisconsin Uprising. Ken Fitzsimmons, Ken Lonnquist, Leyla Sanyer, Adrienne Pagac, and Chris Reeder deserve special mention. Thank you also to Emily Mills, Bryan Hirsh, Jacquelyn Gill, Chris Patteson, and the members of Bonobo Secret Handshake and the Kissers for agreeing to share their audio, video, and images. I received insightful comments upon earlier versions of this article from Andy Hageman, Jon Wolseth, Justin Patch, Dan Sharp, Julia McReynolds, and this journal's anonymous reviewers. I thank them all for their generous critique.

\section{Works Cited}

Averill, Andrew. "Solidarity Sing Along to Test New Wisconsin Capitol Access Rules and Not Apply for Permit." Isthmus, December 14, 2011. http://www.thedailypage.com/daily/article.php?article $=35440$.

Barbour, Clay. “Thousands Gather at Capitol to Protest Walker Budget Bill.” Madison.com, February 16, 2011. http://host.madison.com/news/local/govt-and-politics/thousands-gather-at-capitol-to-protestwalker-budget-bill/article_de45ba12-3935-11e0-9b64-001cc4c002e0.html.

Bauer, Scott. "Wisconsin Lawmakers Flee State to Block Anti-Union Bill." Associated Press, February 17, 2011. http://www.huffingtonpost.com/huff-wires/20110217/us-wisconsin-budget-unions/.

Bloodgood, Elizabeth, and Shelley Deane. "Where Have All the Protest Songs Gone? Social Movements' Message and Their Voice in Politics." Washington D.C., 2005.

Bolter, Jay David, and Richard Grusin. Remediation: Understanding New Media. Cambridge, MA: MIT Press, 2000.

Butler, Judith. Excitable Speech: A Politics of the Performative. New York: Routledge, 1997. 
Cohen, Ronald D. Work and Sing: A History of Occupational and Labor Union Songs in the United States. Crockett, CA: Carquinez Press, 2010.

Cohen-Cruz, Jan. "The Problem Democracy Is Supposed to Solve: The Politics of Community-Based Performance.” In The Sage Hanbook of Performance Studies, 427-45. Thousand Oaks, CA: Sage Publications, 2006. http://dx.doi.org/10.4135/9781412976145.n24

Collins, Jane. “Theorizing Wisconsin's 2011 Protests: Community-Based Unionism Confronts Accumulation by Disposession." American Ethnologist 39, no. 1 (2012): 6-20. http://dx.doi.org/10.1111/j.1548-1425.2011.01340.x

Committee on Assembly Organization. Assembly Bill 11, 2011. http://docs.legis.wisconsin.gov/2011/related/proposals/jr1_ab11.pdf.

Davidoff, Judith. "Solidarity Sing Along Protest 'Fueled' by Wisconsin Capitol Pollice Crackdown." Isthmus, August 22, 2013. http://www.thedailypage.com/isthmus/article.php?article $=40711$.

Denisoff, R. Serge. Sing a Song of Social Significance. Bowling Green State University Popular Press, 1983.

Eyerman, Ron, and Andrew Jamison. Music and Social Movements: Mobilizing Traditions in the Twentieth Century. Cambridge, UK: Cambridge University Press, 1998. http://dx.doi.org/10.1017/CBO9780511628139

- "Social Movements and Cultural Transformation: Popular Music in the 1960s." Media, Culture \& Society 17 (1995): 449-68. http://dx.doi.org/10.1177/016344395017003006

Graeber, David. Fragments of an Anarchist Anthropology. 1st ed. Prickly Paradigm Press, 2004.

Gyourko, Joseph, and Joseph Tracy. An Analysis of Public and Private Sector Wages Allowing for Endogenous Choices of Both Government and Union Status. Working Paper. National Bureau of Economic Research, May 1986. http://www.nber.org/papers/w1920.

Kim, Richard. "We Are All Human Microphones Now.” The Nation, October 3, 2011. http://www.thenation.com/blog/163767/we-are-all-human-microphones-now.

King, Homay. “Antiphon: Notes on The People's Microphone.” Journal of Popular Music Studies 24, no. 2 (2012): 238-46. http://dx.doi.org/10.1111/j.1533-1598.2012.01327.x

McKinley, James, Jr. “At the Protests, the Message Lacks a Melody.” New York Times, October 18, 2011.

Ponder, Jon. “Did Fox Mean to Deceive with 'Palm Tree Lie' - Or Were O'Reilly's Producers Just Being Sloppy?” Pensito Review, March 2, 2011. http://www.pensitoreview.com/2011/03/02/fox-video-ofangry-wisconsin-protesters-shows-palm-trees/.

Roy, William G. Reds, Whites, and Blues: Social Movements, Folk Music, and Race in the United States. Princeton, N.J.: Princeton University Press, 2010.

Sammons, Ted. “I Didn't Say Look; I Said Listen': The People's Microphone, \#OWS, and Beyond.” Sounding Out!, November 21, 2011. http://soundstudiesblog.com/2011/11/21/i-didnt-say-look-isaid-listen-the-peoples-microphone-ows-and-beyond/.

Sanger, Kerran L. "When the Spirit Says Sing!" The Role of Freedom Songs in the Civil Rights Movement. New York: Garland Publishing, Inc., 1995.

Sewell, Abby. "Protesters out in Force Nationwide to Oppose Wisconsin's Anti-Union Bill." Los Angeles Times, February 26, 2011. http://articles.latimes.com/2011/feb/26/nation/la-na-wisconsin-protests20110227. 
Shapiro, Lila. "Wisconsin Protests: State Police Pursue Democratic Lawmakers Boycotting Vote." Huffington Post, February 17, 2011. http:/www.huffingtonpost.com/2011/02/17/wisconsinprotests-scott-walker-police_n_824697.html.

Sorgi, Jay. "Capitol Chaos: State Patrol Goes After Democratic Senators.” Accessed March 20, 2013. http://www.todaystmj4.com/news/local/116469428.html.

Stein, Jason, and Patrick Marley. "Walker Calls for Cuts or Big Layoffs." Milwaukee Journal-Sentinel. February 11, 2011. http://www.jsonline.com/news/statepolitics/115911379.html.

Tiku, Nitasha. "Wisconsin Assembly Passes Anti-Union Bill in Late-Night Sneak Attack." New York Magazine, February 25, 2011.

http://nymag.com/daily/intelligencer/2011/02/wisconsin_assemblys_sneaky_mov.html.

Turino, Thomas. Music as Social Life: The Politics of Participation. Chicago: University of Chicago Press, 2008.

. "Signs of Imagination, Identity, and Experience: A Peircian Semiotic Theory for Music." Ethnomusicology 43, no. 2 (1999): 221-55. http://dx.doi.org/10.2307/852734

“Upwards of 70,000 Rally at State Capitol.” WKOW.com, February 19, 2011. http://www.wkow.com/Global/story.asp?S=14062370.

Willens, Doris. Lonesome Traveler: The Life of Lee Hays. University of Nebraska Press, 1988. 